\title{
Seasonal abundance and bio-efficacy of different insecticides against castor semilooper on castor
}

\author{
Yashdev Singh", Balbir Singh, S. P. Singh and Suman Devi \\ Department of Entomology, CCS Haryana Agricultural University, Hisar 125 004, INDIA \\ *Corresponding author. E-mail: ydev70@gmail.com \\ Received: August 30, 2015; Revised received: May 19, 2016; Accepted: July 23, 2016
}

\begin{abstract}
The present study was conducted at Chaudhary Charan Singh Haryana Agricultural University, Hisar, Regional Research Station, Bawal, Haryana (India). The larvae of castor semilooper remain active from $30^{\text {th }}$ standard weeks to $47^{\text {th }}$ standard weeks. The maximum larval population was recorded on the $32^{\text {th }}$ standard week $(6.1$ larvae per plant) and $38^{\text {th }}$ standard meteorological weeks (6.2 larvae per plant) due the high rainfall, 158 and 120 $\mathrm{mm}$, during these weeks, respectively. Correlation indicates that minimum temperature, evening relative humidity and rainfall exhibited a positive relationship ( $r-0.588,0.577$ and 0.650$)$ with the larval population. Bio-efficacy of four insecticides with different doses was tested against $A$. janata infesting castor crop. One day after spraying thiodicarb @ $468 \mathrm{~g}$ proved best toxicant followed by thiodicarb @ $375 \mathrm{~g}$, deltamethrin @ $11.2 \mathrm{~g}$, deltamethrin @ $10.5 \mathrm{~g}$, quinalphos@ 250 g, quinalphos @ 200 g, novaluron @ $100 \mathrm{~g}$ and novaluron @ $75 \mathrm{~g}$. At three days after spraying, it was found that novaluron @ $100 \mathrm{~g}$ was the most effective followed by novaluron @ $75 \mathrm{~g}$, thiodicarb @ $468 \mathrm{~g}$, deltamethrin @ 11.2 g, thiodicarb @ 375 g, deltamethrin @ $10.5 \mathrm{~g}$, quinalphos @ $250 \mathrm{~g}$ and quinalphos @ $200 \mathrm{~g}$. At seven days after spraying novaluron @ $100 \mathrm{~g}$ proved to be best toxicant followed by novaluron @ $75 \mathrm{~g}$, thiodicarb @ $468 \mathrm{~g}$, thiodicarb @ $375 \mathrm{~g}$, deltamethrin @ $11.2 \mathrm{~g}$, deltamethrin @ $10.5 \mathrm{~g}$, quinalphos@ $250 \mathrm{~g}$ and quinalphos @ $200 \mathrm{~g}$. Novaluron $100 \mathrm{~g}$ was the overall most effective with 75.97 mean per cent reduction in larval population.
\end{abstract}

Keywords- Achaea janata L., Abundance, Chemical control, Incidence

\section{INTRODUCTION}

Castor (Ricinus communis L.) is a highly valued economically important crop for its leaf biomass and non edible seed oil. In India, total area under castor crop for year 2012-2013 is about 13.17 lakh ha with production about 21.77 lakh tones and average yield is about $1653 \mathrm{~kg} / \mathrm{ha}$. In Haryana, particular in south west region, farmers are growing castor as an alternative crop of mustard due to availability of limited irrigation water and losses caused by orobanche (a parasitic weed) of mustard. India, ranks first among the major castor producing countries in the world with 68 per cent of area and 76 per cent of world castor production (Anonymous, 2008).The castor semilooper population have been reported to fluctuation on castor crop. During the crop season this pest mainly occurs during August and September and thereafter, there is decrease in the pest population and pest infestation. Meteorological factors viz. maximum and minimum temperatures, relative humidity and rainfall are most important environmental factors which affect the pest and gives us idea of the environmental factors that regulates cyclic occurrence of the pest. Mohan et al. (2010) studied the pest scenario of castor at various phonological stages from July to November in the farmer's field at Shikaripur, Honnali and Channagiritalukas, they observed that
Achea janata was found from first fortnight of July to second fortnight of November. The peak incidence was during the first fortnight of August to second fortnight of September, with maximum 15.1 larvae per plant on the second fortnight of September and subsequent decline of larval population up to November. There is great need to initiate work on chemical control. In view of the economic significance attached to these insect pests, the present investigations were undertaken to evaluate the efficacy of newer insecticides and find out a suitable pest management strategy. So, study was undertaken to record the seasonal abundance and bioefficacy of different insecticides against castor semilooper on castor.

\section{MATERIALS AND METHODS}

Seasonal abundance and incidence of castor semilooper Location : The present study on seasonal abundance and incidence of castor semilooper was carried out under agro-climatic conditions of South West Haryana at Bawal which is situated at $28^{\circ} 10$ North Latitude, and $76^{\circ} 35$ East Longitude with Altitude of $229 \mathrm{~m}$ above Mean sea level. The mean annual rainfall of Bawal is about $569.61 \mathrm{~mm}$.

Sowing operations: The seed of castor crop hybrid "DCH 177" was procured from the All India Coordinated Research Project on Castor, CCSHAU, Re- 
gional Research Station, Bawal. The seed was soaked in water for 24 hours before sowing. The sowing of castor crop was done on July 6, 2013 at experimental area of Regional Research Station, Bawal by hand dibbling method by dibble 2 seed in each dibble and distance of $120 \mathrm{~cm}$ between row to row. Thinning was done ten days after crop germination and maintaining plant to plant distance of about $60 \mathrm{~cm}$.

Observations of population abundance and incidence of castor semilooper: For studying the seasonal incidence and population of castor semilooper thirty plants were randomly selected and tagged for the observation and frequent visits were made in order to record the first incidence of castor semilooper larvae infesting castor crop was noticed on 2013.The observations were recorded at morning at weekly intervals. The observations were continued till the population of castor semilooper declined upto zero level, which was recorded on $25^{\text {st }}$ November, 2013.

Percentage incidence of castor semilooper on castor : For per cent seasonal incidence of larvae of castor semilooper, infested castor crop plants were recorded from each plots then calculated the percentage incidence by using the following formula

$$
\text { Per cent incidence }=\frac{\text { Number of infested plant }}{\text { Total number of plants }} \times 100
$$

Meteorological data on temperature ${ }^{\circ} \mathrm{C}$ (maximum and minimum),per cent relative humidity (morning and evening) and rainfall ( $\mathrm{mm} /$ week) were obtained from the Regional Research Station, Bawal, Rewari. The data thus obtained, were statistically analysed to determine the correlation coefficient $(r)$ value between the larval abundance and incidence of $A$. janata and the meteorological variables (abiotic factors).

Bio-efficacy of different insecticide: against castor semilooper were carried out under the field condition on the crop sown at experimental area of Regional Research Station, Bawal. There were nine treatments including the control (Table 1) and all the treatments were replicated thricely. The size of each plot was $5 \mathrm{x}$ 5 meter with two meter inter-plot distance. Only one foliar application of different insecticides were applied with knapsack sprayer, on September, 23 when the castor semilooper population cross the economics threshold level which is 4-5 larvae per plant. Second spray was not made because after first spray of insecticides the castor semilooper larvae population remains below the economics threshold level.

Observation of castor semilooper before and after spray: The larval population recorded one day prior to spraying and population of larvae was counted after the first, third and seven day after spraying. The larval population data was recorded on 5 randomly selected and tagged plants in each treatment.

Per cent reduction of larvae $=\frac{Y-Y}{Y} \times \mathbf{Y 0 0}$
Per cent increase of larvae $=\frac{Y-Y}{Y^{4}} \times \mathbf{1 0 0}$
$Y=$ Mean number of larvae in treated plot.
$Y^{\prime}=$ Mean number of larvae in untreated (control) plot.

Statistical analysis: The data obtained for bioefficacy of insecticides was tabulated and analyzed by using AVOVA. Wherever necessary the data were subjected to square root or angular transformation. The data for seasonal abundance was be correlated with the meteorological data obtained from Bawal.

\section{RESULTS AND DISCUSSION}

Seasonal abundance and incidence of castor semilooper: Population dynamics studies on A. janata larvae in relation to meteorological parameters such as maximum and minimum temperatures, relative humidity and rainfall were conducted during $29^{\text {th }}$ to $47^{\text {th }}$ standard meteorological weeks (SMW) (16 July to 25 November) and revealed that the larval population fluctuated from 0.2-6.2 larvae per plant (Table 2). The first

\begin{tabular}{|c|c|c|c|}
\hline $\begin{array}{l}\text { Sr. } \\
\text { No }\end{array}$ & Treatments & $\begin{array}{l}\text { Dosage } \\
\text { (ga.i./ha) }\end{array}$ & Chemical name \\
\hline 1 & $\mathrm{~T}_{1}$ - Rimon10 EC (Novaluron) & 75 & $\begin{array}{l}\text { 1-[3chloro-4-(1, 1, 2-trifloro-2- trifluoromethoxyethoxy) phenyl] - } \\
\text { 3-(2, 6-diflurobenzoyl) urea. }\end{array}$ \\
\hline 2 & T2- Rimon10 EC (Novaluron) & 100 & $\begin{array}{l}\text { 1-[3chloro-4-(1, 1, 2-trifloro-2- trifluoromethoxyethoxy) phenyl] - } \\
\text { 3-(2, 6-diflurobenzoyl) urea. }\end{array}$ \\
\hline 3 & T3- Larvin 75 WP (Thiodicarb) & 375 & $\begin{array}{l}\text { dmethyl } n, n^{1}-\text { thiobis (methylimino) Carbonyloxybisethanimido- } \\
\text { thioate. }\end{array}$ \\
\hline 4 & T4- Larvin 75 WP (Thiodicarb) & 468 & $\begin{array}{l}\text { dmethyl } n, n^{1}-\text { thiobis (methylimino) Carbonyloxybisethanimido- } \\
\text { thioate. }\end{array}$ \\
\hline 5 & T5- Ekalux 25 EC (Quinalphos) & 200 & O, O- diethyl-O-(quinoxalinyl -2-ylphosphorothioate. \\
\hline 6 & T6- Ekalux 25 EC (Quinalphos) & 250 & O, O- diethyl-O-(quinoxalinyl -2-ylphosphorothioate. \\
\hline 7 & T7- Decis2.8 EC(Deltamethrin) & 10.5 & $\begin{array}{l}\alpha, \text { cyano-3-phenoxy benzyl-3-(2, 2- dibromovinyl)-2,2-dimethylcy } \\
\text {-clopropane, carboxylate. }\end{array}$ \\
\hline 8 & T8- Decis2.8 EC(Deltamethrin) & 11.2 & $\begin{array}{l}\alpha, \text { cyano-3-phenoxy benzyl-3-(2, 2- dibromovinyl)-2,2-dimethylcy } \\
\text {-clopropane, carboxylate. }\end{array}$ \\
\hline 9 & T9- Control (No spray) & - & - \\
\hline
\end{tabular}

Table 1. Insecticides used for evaluation of their efficacy against $A$. janata on castor 
Yashdev Singh et al. / J. Appl. \& Nat. Sci. 8 (3): 1321 - 1325 (2016)

Table 2. Larval population and incidence of A. janataon castor vis a vis weather parameters

\begin{tabular}{|c|c|c|c|c|c|c|c|}
\hline \multirow{2}{*}{$\begin{array}{l}\text { Standard Mete- } \\
\text { orological weeks }\end{array}$} & \multirow{2}{*}{$\begin{array}{l}\text { Mean* larval } \\
\text { population / } \\
\text { plant }\end{array}$} & \multirow{2}{*}{$\begin{array}{l}\text { Mean per } \\
\text { cent inci- } \\
\text { dence }\end{array}$} & \multicolumn{2}{|c|}{ Temperature $\left({ }^{\circ} \mathrm{C}\right)$} & \multicolumn{2}{|c|}{ Relative Humidity (\%) } & \multirow{2}{*}{$\begin{array}{l}\begin{array}{l}\text { Rainfall } \\
(\mathbf{m m})\end{array} \\
\end{array}$} \\
\hline & & & Maximum & Minimum & Morning & Evening & \\
\hline 29 & 0.0 & 0.0 & 34.3 & 25.1 & 86.0 & 61.0 & 20.5 \\
\hline 30 & 1.2 & 4.4 & 34.4 & 25.2 & 88.9 & 64.6 & 48.0 \\
\hline 31 & 3.1 & 13.3 & 33.7 & 24.0 & 91.1 & 66.6 & 21.5 \\
\hline 32 & 6.1 & 25.6 & 32.1 & 24.1 & 90.9 & 69.3 & 158.7 \\
\hline 33 & 5.3 & 26.7 & 31.4 & 24.4 & 93.0 & 69.0 & 68.0 \\
\hline 34 & 4.6 & 31.1 & 32.9 & 23.7 & 86.1 & 60.0 & 16.7 \\
\hline 35 & 2.5 & 32.2 & 34.2 & 24.1 & 80.3 & 52.1 & 0.0 \\
\hline 36 & 2.4 & 34.4 & 35.9 & 22.4 & 75.0 & 39.4 & 0.0 \\
\hline 37 & 2.3 & 35.6 & 36.7 & 22.6 & 78.1 & 36.4 & 3.5 \\
\hline 38 & 6.2 & 42.2 & 33.9 & 21.0 & 80.4 & 44.7 & 120.4 \\
\hline 39 & 5.3 & 41.1 & 33.1 & 23.8 & 84.4 & 53.7 & 9.2 \\
\hline 40 & 4.4 & 40.0 & 32.6 & 21.9 & 79.1 & 54.6 & 9.0 \\
\hline 41 & 3.9 & 37.8 & 31.6 & 20.4 & 81.0 & 55.4 & 91.3 \\
\hline 42 & 2.8 & 34.4 & 33.1 & 17.6 & 82.0 & 33.0 & 0.0 \\
\hline 43 & 1.6 & 31.1 & 31.5 & 14.4 & 81.7 & 21.1 & 0.0 \\
\hline 44 & 0.8 & 25.6 & 31.4 & 13.1 & 79.4 & 29.4 & 0.0 \\
\hline 45 & 0.5 & 16.7 & 25.2 & 10.5 & 78.1 & 28.1 & 0.0 \\
\hline 46 & 0.2 & 12.2 & 24.6 & 6.2 & 76.1 & 29.4 & 0.0 \\
\hline 47 & & 5.6 & 27.6 & 6.7 & 76.1 & 28.9 & 0.0 \\
\hline \multicolumn{3}{|c|}{ Correlation values (r) for larval abundance } & $0.373^{\alpha}$ & $0.588 * * *$ & $0.466^{\alpha}$ & $0.577 * *$ & $0.650 * * *$ \\
\hline \multicolumn{3}{|c|}{ Correlation values $(r)$ for per cent incidence } & $0.362^{\alpha}$ & $0.270^{\alpha}$ & $-0.194^{\alpha}$ & $-0.062^{\alpha}$ & $0.150^{\alpha}$ \\
\hline
\end{tabular}

$*=$ Based on 90 plants (30 plants in 3 repeats), $* *=$ Correlation is significant at 0.01 level, $* * *=$ Correlation is significant at 0.05 level, $\alpha=$ Non-significant.

Table 3. Bio-efficacy of different insecticides against $A$. janata infesting castor

\begin{tabular}{|c|c|c|c|c|c|}
\hline \multirow[t]{2}{*}{ Treatment } & \multirow{2}{*}{$\begin{array}{l}\text { Mean number } \\
\text { of larvae be- } \\
\text { fore spray }\end{array}$} & \multicolumn{3}{|c|}{$\begin{array}{l}\text { Mean* \% larval reduction (Days } \\
\text { after spray) }\end{array}$} & \multirow{2}{*}{$\begin{array}{l}\text { Pooled mean } \\
\text { per cent larval } \\
\text { reduction }\end{array}$} \\
\hline & & 1 & 3 & 7 & \\
\hline Novaluron10 EC @75 g a.i. per ha & 5.80 & $\begin{array}{l}46.05 \\
(42.71)\end{array}$ & $\begin{array}{l}81.94 \\
(64.87)\end{array}$ & $\begin{array}{l}90.85 \\
(72.45)\end{array}$ & $\begin{array}{l}72.95 \\
(59.97)\end{array}$ \\
\hline Novaluron10 EC @100 g a.i. per ha & 5.73 & $\begin{array}{l}48.85 \\
(44.32)\end{array}$ & $\begin{array}{l}82.55 \\
(65.29)\end{array}$ & $\begin{array}{l}96.51 \\
(79.20)\end{array}$ & $\begin{array}{l}75.97 \\
(62.94)\end{array}$ \\
\hline Thiodicarb 75 WP @ 375 g a.i. per ha & 5.67 & $\begin{array}{l}58.75 \\
(50.04)\end{array}$ & $\begin{array}{l}71.35 \\
(57.62)\end{array}$ & $\begin{array}{l}80.81 \\
(64.05)\end{array}$ & $\begin{array}{l}70.30 \\
(57.21)\end{array}$ \\
\hline Thiodicarb 75 WP @ 468 g a.i. per ha & 5.60 & $\begin{array}{l}60.64 \\
(51.13)\end{array}$ & $\begin{array}{l}73.66 \\
(59.20)\end{array}$ & $\begin{array}{l}82.13 \\
(64.97)\end{array}$ & $\begin{array}{l}72.14 \\
(58.40)\end{array}$ \\
\hline Quinalphos 25 EC @ $200 \mathrm{~g}$ a.i. per ha & 5.67 & $\begin{array}{l}51.69 \\
(45.95)\end{array}$ & $\begin{array}{l}62.22 \\
(52.09)\end{array}$ & $\begin{array}{l}72.00 \\
(58.09)\end{array}$ & $\begin{array}{l}61.97 \\
(52.01)\end{array}$ \\
\hline Quinalphos25 EC @ $250 \mathrm{~g}$ a.i. per ha & 5.40 & $\begin{array}{l}53.19 \\
(46.81)\end{array}$ & $\begin{array}{l}65.30 \\
(53.92)\end{array}$ & $\begin{array}{l}74.06 \\
(59.39)\end{array}$ & $\begin{array}{l}64.18 \\
(53.35)\end{array}$ \\
\hline Deltamethrin 2.8 EC @ $10.5 \mathrm{~g}$ a.i. per ha & 5.67 & $\begin{array}{l}55.87 \\
(48.36)\end{array}$ & $\begin{array}{l}68.10 \\
(55.63)\end{array}$ & $\begin{array}{l}75.20 \\
(60.16)\end{array}$ & $\begin{array}{l}66.39 \\
(54.68)\end{array}$ \\
\hline Deltamethrin 2.8 EC @11.2 g a.i. per ha & 5.73 & $\begin{array}{l}58.27 \\
(49.75)\end{array}$ & $\begin{array}{l}71.88 \\
(58.02)\end{array}$ & $\begin{array}{l}79.16 \\
(62.83)\end{array}$ & $\begin{array}{l}69.77 \\
(56.84)\end{array}$ \\
\hline Control (No spray) & 5.80 & $\begin{array}{l}1.13 * * \\
(6.09)\end{array}$ & $\begin{array}{l}1.87 * * \\
(7.73)\end{array}$ & $\begin{array}{l}2.24 * * \\
(8.61)\end{array}$ & $\begin{array}{l}1.74 * * \\
(7.52)\end{array}$ \\
\hline $\mathrm{SE}(\mathrm{m})$ & 0.17 & 1.01 & 1.36 & 1.06 & 2.96 \\
\hline C.D. & NS & $3.02 * * *$ & $4.10 * * *$ & $3.21 * * *$ & $(8.95)^{* * *}$ \\
\hline
\end{tabular}

Figures in parentheses are angular transformed values Based on 5 plants /repeat *Only one spray is made at the economics threshold level (4-5 larvae per plant) ** per cent increase *** Significant at 0.05 probability levels, NS= Non-Significant; *Only one spray is made at the economics threshold level (4-5 larvae per plant)

appearance of larvae of $A$. janata was started from the $30^{\text {th }}$ SMW and the population increased onward and reached to 6.1 on $32^{\text {nd }}$ SMW and then the larval popu- lation decreased till the $37^{\text {th }}$ SMW again it was increased rapidly, the maximum number of larvae was found during $38^{\text {th }} \mathrm{SMW}$. The larval population of $A$. 


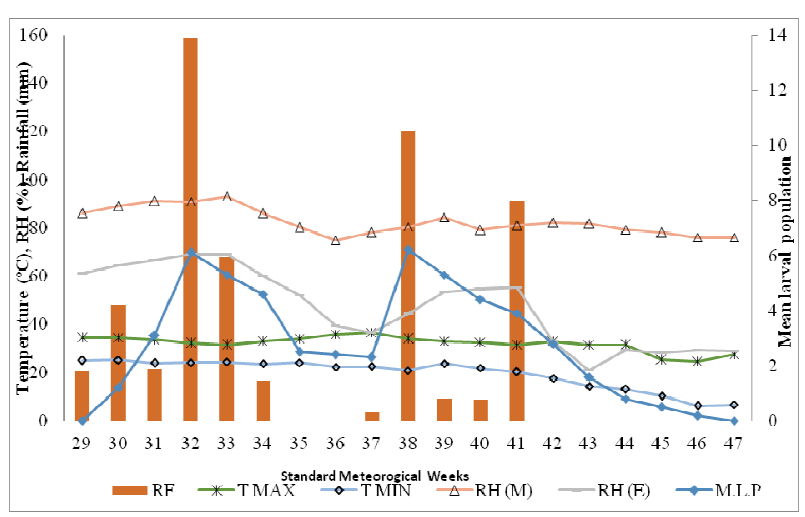

Fig. 1. Mean larval population of castor semilooper and weather parameters

janata were declined from $39^{\text {th }}$ SMW onwards and reached to 0.2 on $46^{\text {th }}$ SMW and becomes almost zero in $47^{\text {th }}$ SMW. Rainfall occurred during the $29^{\text {th }}$ to $34^{\text {th }}$ SMW and then $37^{\text {th }}$ to $41^{\text {st }}$ SMW. Rainfall was recorded highest on the $32^{\text {nd }}$ and $38^{\text {th }} \mathrm{SMW}$, which were 158.7 and $120.4 \mathrm{~mm}$, respectively, whereas the larval population recorded during these standard meteorological weeks were maximum 6.1 and 6.2 larvae per plant, respectively. As the rainfall declined during $35^{\text {th }}$ to $37^{\text {th }} \mathrm{SMW}$ the larval population were also decreased. This showed a positive and significant correlation ( $\mathrm{r}$ $=0.650$ at significant level $0.05 \%$ ) between larval population and rainfall, which is in accordance with Magar (2006) who reported that increase in the larval population of $A$. janata was associated with increase in the rainfall. Whereas Madhuri et al. (2006) reported that rainfall was negatively correlated with the larval population of castor semilooper which may be due to the variation in the environmental condition and time period of investigation. . The minimum temperature fluctuated from 25.2 to $6.2^{\circ} \mathrm{C}$, as the minimum temperature decreased on the $39^{\text {th }}$ to $46^{\text {th }} \mathrm{SMW}$, which decreased from $23.8-6.2^{\circ} \mathrm{C}$ and the larval population were also decreased from 5.3 to 0.2 larvae per plant, respectively, during these SMW (Fig. 2). This showed a significant correlation $(\mathrm{r}=0.588$ at significant level $0.05 \%$ ) between larval population and minimum temperature (Table 2).

The per cent relative humidity in the evening fluctuated from 69.3 to 21.1 . The maximum evening relative humidity was recorded 69.3 per cent during the $32^{\text {nd }}$ SMW, during these weeks the larval population was 6.1 larvae per plant. As the relative humidity decreased from 34 to $37^{\text {th }} \mathrm{SMW}$ and again from 41 to $47^{\text {th }} \mathrm{SMW}$, the larval population were also decreased during this period indicated that a positive and significant correlation ( $\mathrm{r}$ $=0.577$ at significant level $0.01 \%$ ) between larval population and evening relative humidity. The present findings are not at par with the findings of Madhuri et al. (2006) and Rathod and Shetgar (2009) that evening relative humidity was negatively correlated with the larval popula-

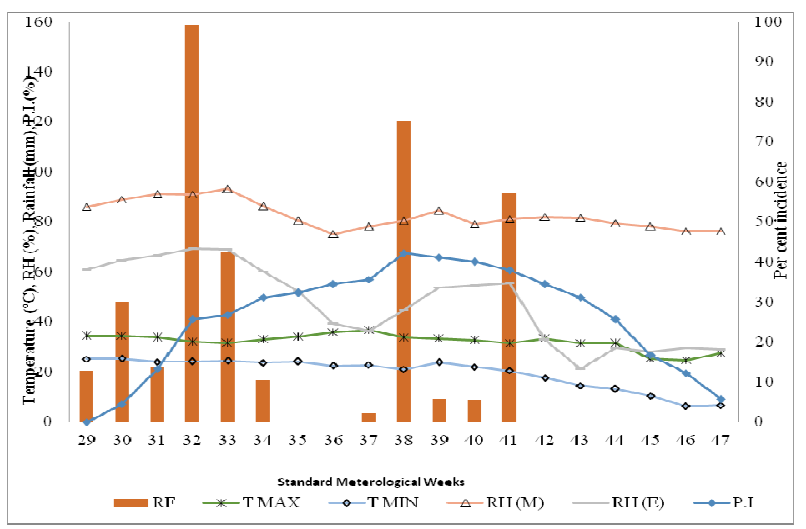

Fig. 2. Per cent incidence of castor semilooper and weather parameter

tion of castor semilooper and morning relative humidity was positively correlated where the range between the morning and evening relative humidity was very low where as in Haryana condition the range was very high as discussed under result.

The per cent infestation ranged from 4.4 to 42.2 per cent. No relationship was observed between the larval population and maximum temperature or morning relative humidity. The present findings are not in line with Madhuri et al. (2006) who reported the minimum temperature was significant and negative whereas the maximum temperature was non-significant and negative relationship. This variation was due to variable climatic condition prevailing at the time of investigation and the range between maximum and minimum temperatures.

Bio-efficacy of different insecticides: The perusal of data presented suggested that at one day after spraying thiodicarb @ 468 g proved to be best toxicant causing 60.64 per cent mean reduction in the larval population, which was at par with thiodicarb @ $375 \mathrm{~g}$ and deltamethrin@11.2 g as their application resulted in 58.75 and 58.27 per cent mean reduction in the larval population (Table 3). Deltamethrin@10.5 g caused mean larval reduction of 55.87 per cent which was at par with quinalphos @ $250 \mathrm{~g}(53.19 \%)$. However, quinalphos@200 g caused 51.69 per cent larval reduction which was at par with novaluron @ $100 \mathrm{~g}$ (48.85\%). Though, novaluron@ @ 75 gm was the least effective with 46.05 per cent mean reduction in larval population after first day of spray. However, all the treatments were significantly superior to control which recorded 1.13 per cent mean increase of larvae population. At three days after spraying, it was found that novaluron@ $100 \mathrm{~g}$ was the most effective with 82.55 per cent mean reduction in the larval population which was at par with novaluron@ 975 g causing 81.94 per cent mean reduction in the larval population. Similarly, thiodicarb@468 g caused larval reduction of 73.66 per cent which was at par with deltamethrin @ $11.2 \mathrm{~g}$ and thiodicarb@375 g which caused 71.88 and 71.35 per cent mean reduction in the larval population, re- 
spectively. Deltamethrin @ 10.5 g caused 68.10 reduction in larval population which was at par with quinalphos@250 g which reduced 65.30 per cent larval reduction. Quinalphos @ $200 \mathrm{~g}$ was the least effective with 62.22 per cent mean reduction in larval population. However, all the treatments were significantly superior to control which recorded 1.87 per cent increase in larval population (Table 3 ).

At seven days after spraying, novaluron @ 100g was found most effective with 96.51 per cent mean reduction in the larval population, while quinalphos @ $200 \mathrm{~g}$ was the least effective with 72.00 per cent mean larval reduction. Novaluron@ 975 g caused 90.85 per cent larval reduction, while thiodicarb @ $468 \mathrm{~g}$ caused 82.13 per cent larval reduction which was at par with thiodicarb@375 g and deltamethrin@11.2 g which caused 80.81 and 79.16 per cent larval reduction, respectively. Deltamethrin @ 10.5 g results in 75.20 per cent larval reduction which was at par with quinalphos @ $250 \mathrm{~g}$ and quinalphos @ $200 \mathrm{~g}$ which caused 74.06 and 72.00 per cent reduction in larval population, respectively. However, all the treatments were significantly superior to control which recorded 2.24 per cent increase in larval population. On the basis of mean per cent reduction in larval population at different intervals after spraying of insecticides, it is evident that all the insecticides proved significantly better than control. Novaluron@ $100 \mathrm{~g}$ recorded significant mortality over other treatments. Novaluron @ $100 \mathrm{~g}$ was at par with novaluron@75 g, thiodicarb @ $468 \mathrm{~g}$, thiodicarb @ $375 \mathrm{~g}$ and deltamethrin @ $11.2 \mathrm{~g}$ with their mean larvae mortality ranged 75.97 to 69.77 per cent. Deltamethrin@10.5 g caused 66.39 per cent larval reduction which was at par with quinalphos @ $250 \mathrm{~g}$ and quinalphos@200 g which causes 64.18 and 61.97 per cent mean reduction in larval population. Narayanamma et al. (2010) reported that thiodicarb gave more larval reduction $(66.7 \%)$ after one day of spraying as compared to novaluron which gave 48.3 per cent larval reduction. Novaluron is a growth regulator, so larval mortality increased as increase in the time of spraying of insecticide. All the insecticides continued to give higher mortality of $A$. janata larvae whereas the novaluron gave maximum mortality after increase in the time duration due to growth regulator in nature. Grewal et al. (1988) reported the efficacy of nine insecticides viz., deltamethrin, fenvalerate, permethrin and cypermethrin, at $0.01 \%$, and endosulfan, carbaryl, chlorpyriphos, quinalphos and fenitrothion at $0.05 \%$ against $A$. janata were evaluated at Ludhiana. Chlorpyrifos, fenvalerate, quinalphos and deltamethrin gave a quick knockdown effect, causing 70.3, 64.3, 63.4 and $56.6 \%$ mortality respectively, one day after spraying. In the case of endosulfan, chlorpyrifos, quinalphos, fenitrothion, permethrin and cypermethrin the mortal- ity had increased to 100.0 per cent four days after spraying.

\section{Conclusion}

Population abundance studies on Achea janata larvae in relation to meteorological parameters such as maximum and minimum temperatures, relative humidity and rainfall were conducted during $29^{\text {th }}$ to $47^{\text {th }}$ standard meteorological weeks (16 July to 25 November). All the insecticides proved better than the control at all the intervals of observations. The effectiveness of the insecticides increased with the intervals of time after spraying. One day after spraying thiodicarb @ $468 \mathrm{~g}$ proved to be best toxicant followed by thiodicarb @ $375 \mathrm{~g}$, deltamethrin@11.2 g, deltamethrin@10.5 g, quinalphos@250 g, quinalphos@200 g, novaluron @ $100 \mathrm{~g}$ and novaluron @ $75 \mathrm{~g}$. At three days after spraying, it was found that novaluron@ $100 \mathrm{~g}$ was the most effective followed by novaluron@ $975 \mathrm{~g}$, thiodicarb@468 g, deltamethrin@11.2 g, thiodicarb@ $375 \mathrm{~g}$, deltamethrin @ $10.5 \mathrm{~g}$, quinalphos @ $250 \mathrm{~g}$ andquinalphos@200 g. At seven days after spraying novaluron@100 g proved to be best toxicant followed bynovaluron@75g, thiodicarb@468 g, thiodicarb @ $375 \mathrm{~g}$, deltamethrin@11.2 g, deltamethrin@10.5 g, quinalphos@250 g andquinalphos@200 g. However, all the treatments were found to be superior to control. Novaluron@100 g was found to be most effective with overall 75.97 mean reduction in larval population

\section{REFERENCES}

Anonymous (2008). National multi-commodity exchange of India limited. $4^{\text {th }}$ Floor H.K. House, B/h Jivabhai Chambers, Ashram Road, Ahmedabad, Gujrat.

Grewal, G.S. , Garcha, H.S. and S. Gurdip (1988). Chemical control of castor semilooper, Achaea janata L. (Lepidoptera: Noctuidae) on castor in Punjab. Journal of Research Punjab Agricultural University, 25(4): 581-86.

Madhuri, C. , G.R. Rao, P.A. Rao and V.S. Rao (2006). Incidence of lepidopteron pest of castor (Ricinuscommunis L.). Andhra Agricultural Journal, 53(1/2): 80-82.

Magar, S.A. (2006). Population dynamics and field lifetables of lepidopterous pests of soyabean. M.sc.Thesis, submitted to Marathwada Agricultural University, Parbhani. pp 86.

Mohan, I.N. , M.A.A. Kumar, M. Manjunatha and B.K. Shivanna (2010). Survey for the pests of castor and natural enemies of castor semilooper. Environment and Ecology, 28(1): 558-63.

Narayanamma, V.L. , A.V. Reddy and T.V.K. Singh (2010). Evaluation of newer insecticides for the management of defoliators and capsule borer in castor. Indian Journal Plant Protection, 38(2): 144-46.

Rathod, A.D. and Shetgar, S.S. (2009). Population dynamics and field life-tables of lepidopterous pests of castor. M.Sc. pp 56. 